\title{
EFEKTIVITAS BIJI KELOR SEBAGAI KOAGULAN ALAMI PADA PENGOLAHAN LIMBAH CAIR TAHU MELALUI PROSES ANAEROBIK-AEROBIK
}

\author{
Laily Isna Ramadhani ${ }^{1}$, Yurike Dwiayu Rahmaningsi ${ }^{1}$, Nanda Ravenia Amanda ${ }^{1}$, \\ Herawati Budiastuti ${ }^{1 *}$ \\ ${ }^{1}$ Jurusan Teknik Kimia, Politeknik Negeri Bandung, \\ Jalan Gegerkalong Hilir, Ds.Ciwaruga, Bandung 40012 \\ *Email: herabudi@polban.ac.id
}

\begin{abstract}
ABSTRAK
Limbah cair tahu merupakan salah satu limbah cair dengan kandungan organik yang tinggi dan berpotensi merusak lingkungan. Pada penelitian ini digunakan dua metode pengolahan dengan mengkombinasikan metode pengolahan biologi dan proses koagulasi-flokulasi menggunakan koagulan alami, biji kelor. Tujuan dari penelitian ini adalah mempelajari pengaruh dosis dan ukuran partikel koagulan terbaik. Dosis biji kelor divariasikan dari 1.000, 2.000, 3.000, dan $4.000 \mathrm{ppm}$. Dosis terbaik digunakan untuk menentukan ukuran partikel koagulan terbaik dengan variasi ukuran 250, 500, 1.000, dan $2.000 \mu \mathrm{m}$. Hasil penelitian menunjukkan bahwa dosis biji kelor terbaik untuk metode 1 (aerobik dan koagulasi flokulasi) adalah $2.000 \mathrm{ppm}$ dan untuk metode 2 (kombinasi anaerobik-aerobik dan koagulasi flokulasi) adalah 4.000 ppm. Ukuran partikel terbaik yaitu $500 \mu \mathrm{m}$ untuk kedua metode dengan efisiensi penurunan kekeruhan sebesar $94,57 \%$ untuk efluen metode 1 dan $78,28 \%$ untuk efluen metode 2.
\end{abstract}

Kata kunci: Limbah cair tahu, biji kelor,koagulan alami, koagulasi- flokulasi

\begin{abstract}
Tofu wastewater is one of the pollutant wastewater that potentially cause the serious damage to the environment due to its high organic content. The combination of biology method in the help of microorganism and coagulation-flocculation method using kelor seed were applied in this study. This research aims were determining the best dose and the optimum size of coagulant. Doses variation were $1,000,2,000,3,000$ and 4,000 ppm of coagulant. The best dose resulted would be used to determine the optimum size of coagulant by variating $250,500,1,000$ and $2,000 \mu \mathrm{m}$. The result showed that 2,000 ppm was the best coagulant dose for the first method (aerobic and coagulation-flocculation method) and 4,000 ppm was the optimum dose for the second method (combination of anaerobic-aerobic and coagulation-flocculation method). 500 $\mu \mathrm{m}$ was determined as the optimum particle size of the coagulant for both methods with $\%$ removal turbidity level were $94,57 \%$ for the first method and $78,28 \%$ for the second method.
\end{abstract}

Keywords:Tofu wastewater, kelor seed, natural coagulant, coagulation-flocculation

\section{PENDAHULUAN}

Limbah cair tahu adalah salah satu limbah cair yang dihasilkan dalam proses produksi tahu dengan kandungan zat organik yang tinggi sehingga berpotensi mencemari lingkungan. Kandungan organik limbah cair tahu yang terukur sebagai COD terbilang tinggi yaitu berkisar $13.837 \mathrm{mg} / \mathrm{L}$ (Rahmaningsih \& Amanda, 2019). 
Studi mengenai pengolahan limbah cair tahu sudah banyak dilakukan, diantaranya terangkum dalam Tabel 1. di bawah ini

Tabel 1. Teknologi Pengolahan Limbah Tahu (Rozana dkk., 2011)

\begin{tabular}{|c|c|c|c|}
\hline \multirow[b]{2}{*}{$\begin{array}{c}\% \\
\text { Removal }\end{array}$} & \multicolumn{3}{|c|}{ Teknologi Pengolahan } \\
\hline & $\begin{array}{c}\text { Adsorben } \\
\text { Zeolit }\end{array}$ & $\begin{array}{c}\text { Proses } \\
\text { Biofilter } \\
\text { Anaerobik } \\
\text { dan Aerob }\end{array}$ & $\begin{array}{l}\text { Koagulasi- } \\
\text { flokulasi } \\
\text { dan } \\
\text { ultrafiltrasi }\end{array}$ \\
\hline BOD5 & $23,96 \%$ & $89,4 \%$ & $75,84 \%$ \\
\hline COD & $15,06 \%$ & $88,2 \%$ & $78,19 \%$ \\
\hline TSS & - & $94 \%$ & $97,84 \%$ \\
\hline
\end{tabular}

Pada Tabel 1 disajikan informasi mengenai proses pengolahan limbah menggunakan. beberapa teknologi diantaranya menggunakan zeolit sebagai adsorben, proses biofilter anaerobik dan aerob dan juga menggunakan proses koagulasiflokulasi. Dari beberapa perbandingan teknologi tersebut diperoleh hasil efisiensi penurunan parameter pencemar terbaik adalah proses biofilter anaerobik dan aerobik dengan kemampuan penurunan kadar COD mencapai 88,2\%. Proses pengolahan dengan melibatkan mikroorganisme merupakan metode pengolahan yang umumnya dipakai dalam mendegradasi kandungan organik dalam limbah. Hanya saja proses ini masih menyisakan efluen yang berbau tidak sedap dan berwarna keruh. Dengan demikian diperlukan proses tambahan untuk menghasilkan efluen dengan kualitas yang lebih baik.

Tingginya kandungan pencemar yang terukur sebagai COD pada limbah cair tahu, didukung dari studi literatur di atas, maka pada penelitian ini proses pengolahan limbah cair tahu dilakukan dalam dua tahapan utama yaitu tahap pengolahan biologi secara aerobik dan kombinasi anaerobik-aerobik dan tahap koagulasi-flokulasi sebagai penyempurna proses pengolahan. Proses biologi dimaksudkan untuk menurunkan nilai COD dalam limbah dan proses koagulasi-flokulasi dimaksudkan untuk menurunkan tingkat kekeruhan efluen. Dari penelitian yang dilakukan Oktariany dan Kartohardjono (2018), tingkat kekeruhan limbah cair tahu dapat diturunkan sebesar $45 \%$ melalui proses koagulasi-flokulasi mengunakan PAC sebagai koagulannya.

Koagulan alami yang digunakan dalam penelitian ini adalah salah satu koagulan alami yang ketersediaannya sangat banyak di Indonesia yaitu biji kelor. Biji kelor memiliki kandungan protein yang cukup tinggi dimana hasil studi yang dilakukan oleh Hidayat (2009) membuktikan bahwa kandungan protein dalam biji kelor memiliki muatan positif sehingga termasuk polielektrolit kationik. Muatan positif dalam biji kelor akan memudahkan terbentuknya flok ketika berikatan dengan muatan negiatif dalam partikel koloid sehingga proses pengendapan akan lebih cepat terjadi. Dalam beberapa tahun terakhir ini, tingginya kesadaran masyarakat terhadap isu-isu lingkungan meningkatkan ketertarikan terhadap studi mengenai koagulan alami dimana lebih murah karena tersedia melimpah di alam, mudah terurai, rendah akan zat-zat berbahaya dan biasanya memiliki luas permukaan yang besar sehingga meningkatkan efisiensi proses koagulasi (Freitas dkk., 2015). Penggunaan koagulan alami tentunya bisa menjadi pilihan yang menguntungkan khususnya bagi negara tropis seperti Indonesia yang memiliki potensi sumber daya alam yang tinggi. Studi mengenai penggunaan koagulan alami dalam menurunkan turbiditas air limbah sudah banyak dilakukan sebelumnya seperti biji buncis (Mishra \& Bajpai, 2006), biji pinus (Hussain dkk., 2019), biji pohon ek dan kastanya (Klašnja dkk., 2009). 


\section{METODE}

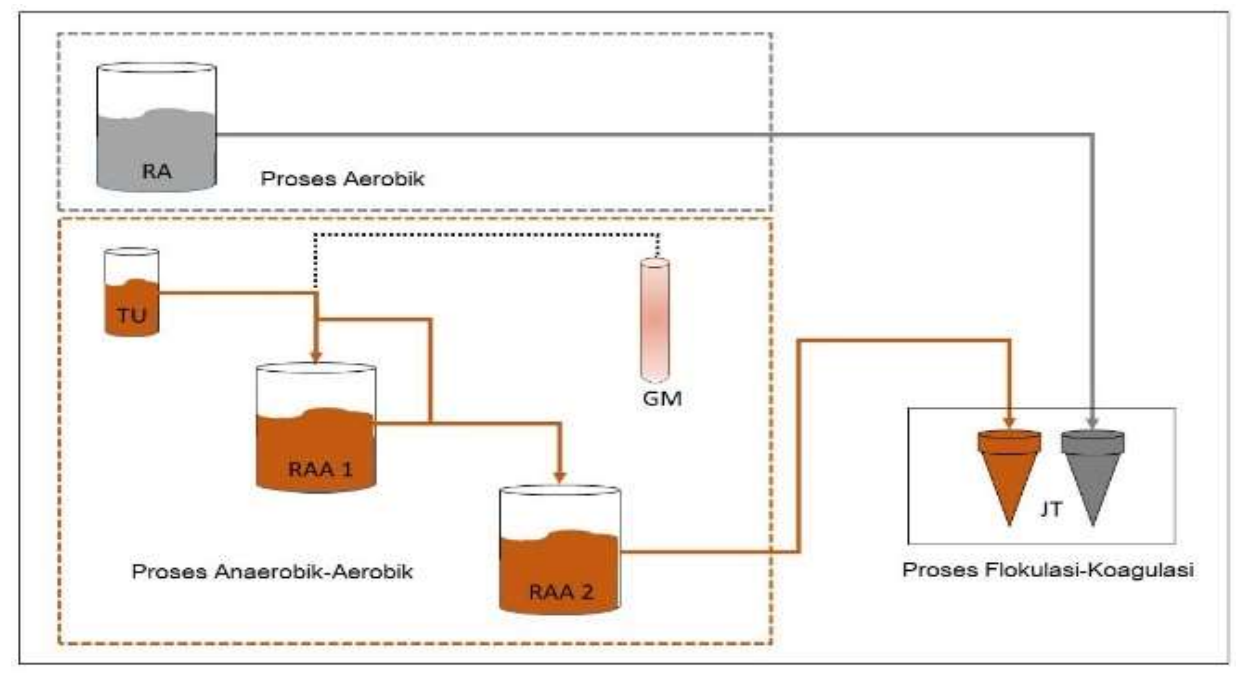

Gambar 1. Alur proses pengolahan limbah cair secara anaerob-aerob dan koagulasi-flokulasi

Alat

Limbah cair tahu dalam penelitian ini diolah menggunakan 2 metode yaitu melalui proses aerobik dan koagulasiflokulasi sebagai metode 1 dan melalui kombinasi proses anaerobik-aerobik, dan koagulasi-flokulasi sebagai metode 2. Pada penelitian ini digunakan 2 rangkaian reaktor aerobik $30 \mathrm{~L}$ yang dilengkapi dengan aerator, pompa sirkulasi dan tangka umpan (TU). RA merupakan reaktor aerobik yang digunakan pada metode 1 sedangkan RAA1 adalah reaktor anaerobik yang merupakan bagian dari metode 2 yang kemudian hasil keluaran dari reaktor ini dialirkan ke reaktor aerobik (RAA2). RAA1 dilengkapi dengan gasometer (GM) dioperasikan pada penelitian lain. Efluen dari RA dan RAA2 kemudian diolah lebih lanjut dalam jar test sebagai tempat terjadinya proses koagulasi-flokulasi (Gambar 1.)

Biji kelor digunakan sebagai koagulan alami untuk membantu proses pengendapan dimana proses ini dilakukan pada $\mathrm{pH}$ 6, mengacu pada $\mathrm{pH}$ optimum proses koagulasi-flokulasi dengan koagulan biji kelor yang dilakukan oleh Hendrawati (2016) yaitu pada $\mathrm{pH}$ 6-8. Proses koagulasi dilakukan selama 3 menit dengan kecepatan pengadukan 100 RPM, sedangkan untuk proses koagulasi digunakan pengadukaan dengan kecepatan 40 RPM selama 12 menit. Untuk mendapatkan dosis koagulan terbaik, digunakan variasi dosis 1.000, 2.000, 3.000, dan 4.000 ppm. Dosis koagulan biji kelor dengan efisiensi penurunan tingkat kekeruhan terbaik akan digunakan untuk menentukan ukuran partikel koagulan optimum dengan variasi ukuran partikel 250, 500, 1.000 dan $2.000 \mu \mathrm{m}$.

\section{Bahan}

Bahan baku yang digunakan dalam penelitian ini terlampir dalam Tabel 1 beserta dengan spesifikasinya.

Tabel 1. Bahan Baku

\begin{tabular}{lll}
\hline No. & \multicolumn{1}{c}{ Bahan } & \multicolumn{1}{c}{ Spesifikasi } \\
\hline 1 & Limbah cair & COD: $1.000 \mathrm{mg} / \mathrm{L}$ \\
& industri tahu & $\mathrm{pH}: 5.85$ \\
& & Kekeruhan:115,8 NTU \\
2 & Lumpur Aktif & $\begin{array}{l}\text { BOD }: 1000 \mathrm{mg} / \mathrm{L} \\
\mathrm{pH}: 5.3\end{array}$ \\
3 & Biji kelor & 100 gram \\
\hline
\end{tabular}




\section{HASIL DAN PEMBAHASAN}

Penelitian diawali dengan pengolahan limbah cair tahu melalui proses aerobik dan proses kombinasi anaerobik-aerobik dimana kedua reaktor dijalankan secara kontinyu dengan efluen sebesar $500 \mathrm{~mL}$ setiap 3 hari sekali untuk menurunkan kadar polutan yang terukur sebagai COD. Penggunaan HRT (Hydraulic Retention Time) besar dimaksudkan agar efisiensi degradasi kandungan organik dalam limbah lebih maksimal.

Gambar 2 Menunjukkan konsentrasi COD yang fluktuatif, namun demikian terlihat kecenderungan penurunan konsentrasi COD yang signifikan baik pada proses aerobik di reaktor aerobik metode 1 (RA) maupun di reaktor aerobik metode 2 (RAA2) dimana efisiensi penurunan kadar COD mencapai $89.744 \%$ untuk reaktor aerobik (RA) dan $88.292 \%$ untuk reaktor kombinasi (RAA2) dimana perbedaannya tidak signifikan. Selain karena penggunaan HRT panjang, tingginya efisiensi penurunan COD juga didukung dari upaya kontrol $\mathrm{pH}$ yang dilakukan selama proses berlangsung. Upaya control $\mathrm{pH}$ ini penting dilakukan untuk menjaga kondisi operasi reaktor agar tetap stabil dikondisi yang ideal untuk pertumbuhan bakteri aerobik dan anaerobik.

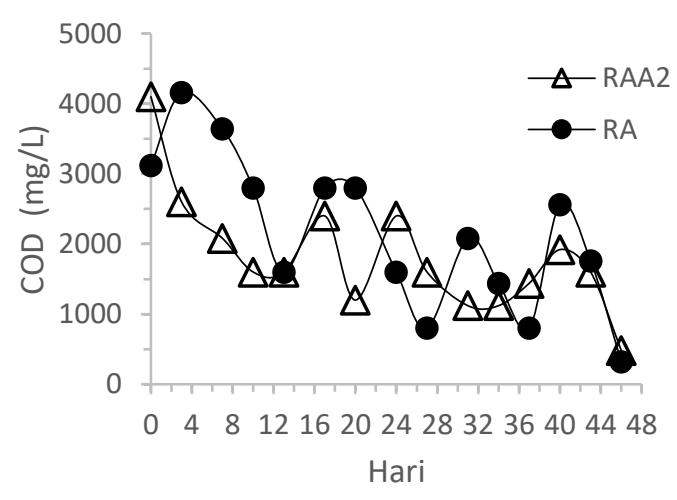

Gambar 2. Profil Konsentrasi COD Pada Proses Aerobik Metode 1 (RA) dan di Reaktor Aerobik Metode 2 (RAA 2)

\section{Proses Koagulasi-Flokulasi \\ Variasi Dosis}

Variasi dosis dilakukan dengan memvariasikan dosis masing-masing koagulan sebesar 1.000, 2.000, 3.000 dan $4.000 \mathrm{ppm}$ terhadap efluen proses aerobik (Metode 1.) maupun proses kombinasi anaerobik-aerobik (Metode 2.) Untuk proses koagulasi, digunakan kecepatan pengadukan sebesar $100 \mathrm{rpm}$ selama 3 menit sedangkan untuk proses flokulasi dilakukan dengan kecepatan pengadukan $40 \mathrm{rpm}$ selama 12 menit.

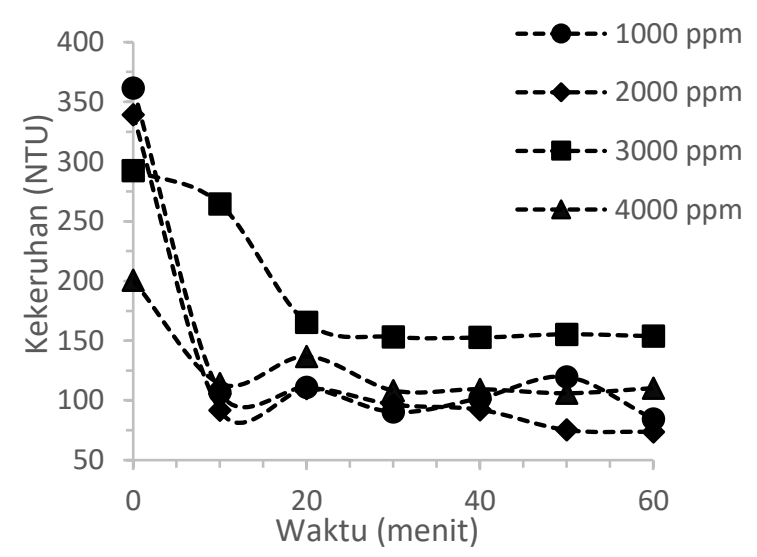

Gambar 3. Pengaruh Variasi Dosis Koagulan Terhadap Penurunan Kekeruhan pada Metode 1

Berdasarkan Gambar 3 tingkat kekeruhan pada semua variasi dosis menunjukkan penurunan, untuk variasi dosis 1.000 ppm, 2.000 ppm dan 4000 ppm kecepatan penurunan tingkat kekeruhan relatif sama yaitu pada menit ke-10 dan tidak mengalami perubahan yang signifikan pada menit-menit selanjutnya. Berbeda dengan variasi dosis 3.000 ppm dimana penurunan tingkat kekeruhan baru stabil dimenit ke-20 dengan nilai kekeruhannya lebih tinggi dibandingkan variasi dosis lainnya. Persentase penurunan tingkat kekeruhan pada semua variasi dosis tertera pada Tabel 2 sebagai berikut. 
Tabel 2. Efisiensi Penurunan Kekeruhan

\begin{tabular}{cc}
\multicolumn{2}{c}{ dengan Varisi Dosis Koagulan Metode $\mathbf{1}$} \\
\hline Efisiensi Penurunan & Kekeruhan $(\%)$ \\
\hline $1.000 \mathrm{ppm}$ & $76,63 \%$ \\
$2.000 \mathrm{ppm}$ & $78,28 \%$ \\
$3.000 \mathrm{ppm}$ & $47,42 \%$ \\
$4.000 \mathrm{ppm}$ & $45,01 \%$ \\
\hline
\end{tabular}

Berdasarkan Tabel 2 diperoleh efisiensi penyisihan kekeruhan terbesar diperoleh sebesar 78,28\% ketika digunakan koagulan dengan dosis sebesar $2.000 \mathrm{ppm}$. Persentase penurunan kekeruhan kemudian menurun ketika digunakan variasi dosis yang lebih besar dari $2.000 \mathrm{ppm}$. Hal ini dikarenakan berlebihnya dosis koagulan yang digunakan meningkatkan nilai TSS dalam limbah yang berakibat meningkatnya tingkat kekeruhan. Digunakannya koagulan di atas dosis optimum menyebabkan kelebihan koagulan tidak dapat berinteraksi dengan partikel koloid sehingga menyebabkan meningkatnya kekeruhan (Hendrawati dkk., 2003). Selain itu menurut Weber (1972) dalam Kristijarti dkk. (2013), penambahan dosis koagulan yang berlebih membuat koloid kembali stabil dikarenakan tidak adanya ruang untuk membentuk penghubung partikel. Dari hasil tersebut diperoleh dosis terbaik koagulan biji kelor dalam mengolah efluen pengolahan aerobik adalah $2.000 \mathrm{ppm}$.

Dari Gambar 4 untuk proses koagulasi-flokulasi efluen metode 2 menunjukkan trend penurunan yang sama kecuali pada variasi dosis 1.000 ppm dimana tingkat kekeruhan baru berkurang secara signifikan pada menit ke-20. Hal ini dikarenakan untuk variasi dosis tersebut penurunan tingkat kekeruhan masih belum optimal, terkonfirmasi dari data persentase penurunan kekeruhan yang terlampir pada Tabel 3 dibawah ini.

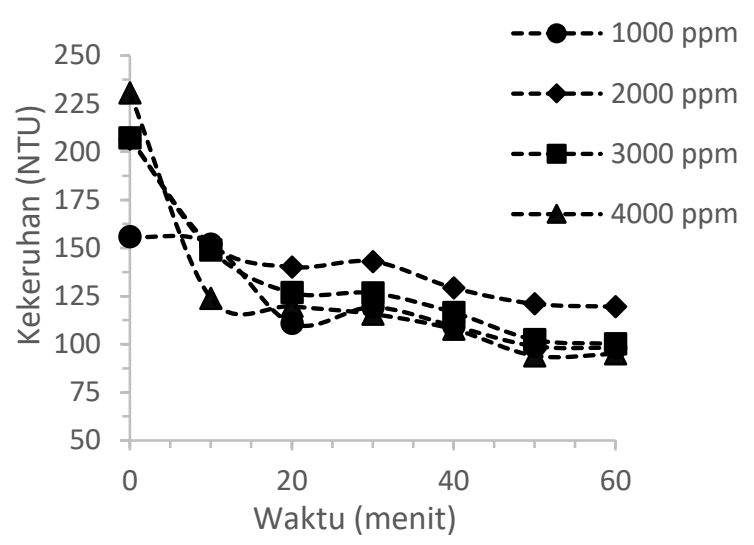

Gambar 4. Pengaruh Variasi Dosis Koagulan Terhadap Penurunan Kekeruhan pada Metode 2

Tabel 3. Efisiensi Penurunan Kekeruhan dengan Variasi Dosis Koagulan Metode 2

\begin{tabular}{cr}
\hline Efisiensi Penurunan & Kekeruhan $(\%)$ \\
\hline $1.000 \mathrm{ppm}$ & $37,01 \%$ \\
$2.000 \mathrm{ppm}$ & $42,16 \%$ \\
$3.000 \mathrm{ppm}$ & $51,66 \%$ \\
$4.000 \mathrm{ppm}$ & $58,80 \%$ \\
\hline
\end{tabular}

Dari Tabel 3 diperoleh persentase penurunan kekeruhan pada berbagai variasi dosis koagulan, dimana tingkat penurunan kekeruhan meningkat seiring digunakannya variasi dosis yang semakin besar. Efisiensi penurunan kekeruhan tertinggi diperoleh sebesar $58,81 \%$ ketika digunakan dosis koagulan $4.000 \mathrm{ppm}$. Hal ini berbanding terbalik dengan hasil penurunan kekeruhan pada metode 1 dimana persentase efisiensi penurunan kekeruhan justru lebih besar ketika digunakan variasi dosis koagulan yang kecil. Hasil ini mengindikasikan bahwa penyebab utama kekeruhan pada efluen proses anaerobik-aerobik disebabkan karena komponen utama yang terkandung di dalamnya adalah koloid (Kristijarti dkk., 2013). Meskipun efisiensi tertinggi yang diperoleh pada metode 2 lebih kecil dibandingkan metode 1 namun untuk variasi dosis $4.000 \mathrm{ppm}$ terbilang sudah efektif menurut Gurnham (1955) karena tingkat penurunannya lebih dari $50 \%$. 


\section{Variasi Ukuran Partikel Koagulan}

Tahapan penelitian berikutnya adalah melakukan variasi partikel koagulan pada metode 1 maupun metode 2. Pada tahap ini digunakan dosis optimum yang merupakan hasil dari variasi dosis koagulan pada tahap sebelumnya dimana dosis optimum untuk koagulan biji kelor adalah 2.000 ppm untuk metode 1 dan $4.000 \mathrm{ppm}$ untuk metode 2.

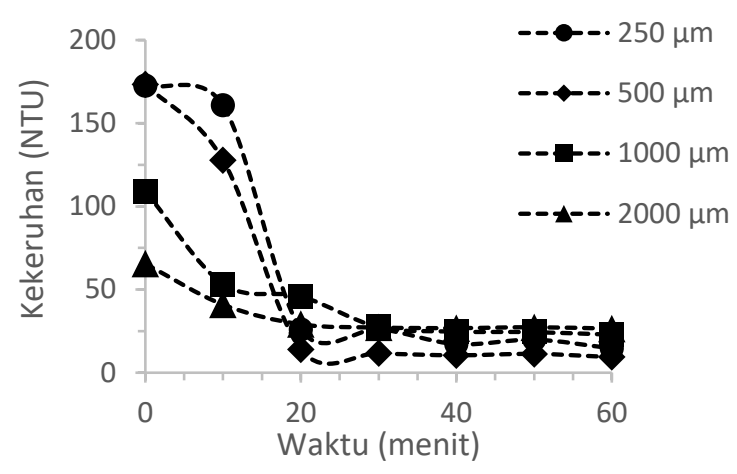

Gambar 5. Pengaruh Variasi Ukuran Koagulan Terhadap Penurunan Kekeruhan pada Metode 1

$\begin{array}{ccr}\text { Gambar } & 5 & \text { menunjukkan } \\ \text { perbedaan } & \text { kecepatan } & \text { penurunan }\end{array}$ kekeruhan pada variasi ukuran koagulan $250 \mu \mathrm{m}$ dan $500 \mu \mathrm{m}$ dimana baru terjadi pada menit ke-20. Variasi ukuran koagulan $1.000 \mu \mathrm{m}$ dan $2.000 \mu \mathrm{m}$ yang sudah mengalami penurunan yang signifikan pada menit ke-10. Meskipun kecepatan penurunan kekeruhannya lebih lambat, efisiensi penurunan akhir pada variasi dosis $250 \mu \mathrm{m}$ dan $500 \mu \mathrm{m}$ dimenit ke-60 jauh lebih tinggi dibandingkan dengan koagulan dengan yang lebih besar (Tabel 4).

Tabel 4. Efisiensi Penurunan Kekeruhan dengan Variai Ukuran Koagulan pada Metode 1

\begin{tabular}{cc}
\hline Efisiensi Penurunan & Kekeruhan $(\%)$ \\
\hline $250 \mu \mathrm{m}$ & $91,48 \%$ \\
$500 \mu \mathrm{m}$ & $94,57 \%$ \\
$1.000 \mu \mathrm{m}$ & $79,04 \%$ \\
$2.000 \mu \mathrm{m}$ & $59,53 \%$ \\
\hline
\end{tabular}

Variasi ukuran yang lebih kecil memiliki kemampuan untuk menurunkan tingkat kekeruhan yang lebih baik dibandingkan ukuran koagulan yang lebih besar. Terlihat dari tingginya efisiensi penurunan kekeruhan pada koagulan dengan ukuran $250 \mu \mathrm{m}$ dan $500 \mu \mathrm{m}$ dengan efisiensi penurunan maksimum mencapai $94,57 \%$ pada koagulan dengan ukuran partikel $500 \mu \mathrm{m}$. Hal ini dikarenakan koagulan dengan ukuran kecil memiliki luas permukaan yang besar sehingga memudahkan dalam pembentukan flok. Hasil ini sesuai dengan studi yang telah dilakukan oleh Wardani dan Agung (2016) dimana diameter partikel memiliki pengaruh besar terhadap penurunan kekeruhan. Diameter partikel koagulan yang kecil memiliki luas kontak antar koagulan yang besar sehingga mempermudah terbentuknya flok dalam limbah.

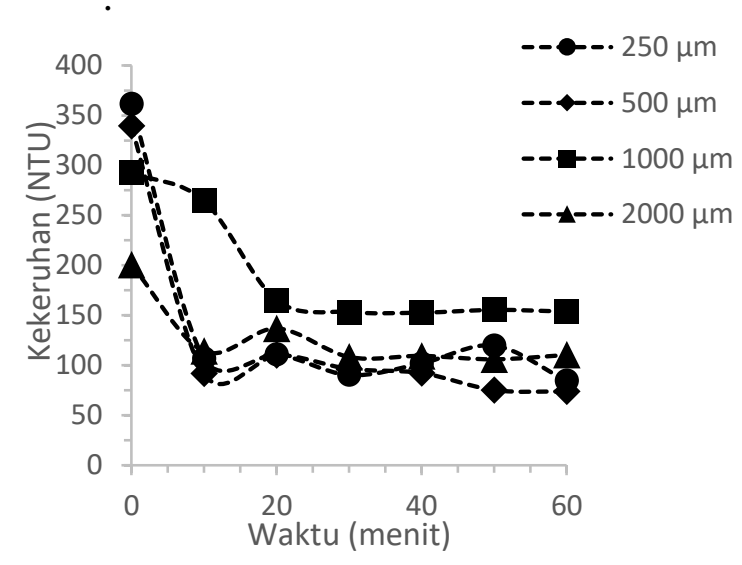

Gambar 6. Pengaruh Variasi Ukuran Koagulan Terhadap Penrunan Kekeruhan pada Metode 2

Tabel 5. Efisiensi Penurunan Kekeruhan dengan Variai Ukuran Koagulan pada Metode 2

\begin{tabular}{cc}
\hline Efisiensi Penurunan & Kekeruhan $(\%)$ \\
\hline $250 \mu \mathrm{m}$ & $76,63 \%$ \\
$500 \mu \mathrm{m}$ & $78,28 \%$ \\
$1.000 \mu \mathrm{m}$ & $47,42 \%$ \\
$2.000 \mu \mathrm{m}$ & $45,01 \%$ \\
\hline
\end{tabular}


Dari Gambar 6 terlihat semua variasi ukuran partikel memiliki laju penurunan kekeruhan yang sama, kecuali koagulan dengan ukuran 1.000 $\mu \mathrm{m}$ dimana penurunan kekeruhan secara signifikan baru terjadi dimenit ke-20 dengan tingkat kekeruhan yang lebih tinggi dibandingkan dengan variasi dosis lainnya. Dari Tabel 5 terlihat bahwa untuk efluen metode 2, efisiensi penurunan kekeruhan terbaik terjadi ketika digunakan biji kelor dengan ukuran partikel adalah $500 \mu \mathrm{m}$ dengan efisiensi penurunan sebesar 78,28\%. Efisiensi penyisihan tingkat kekeruhan juga menurun ketika digunakan variasi ukuran pasrtikel $1.000 \mu \mathrm{m}$ dan 2.000 $\mu \mathrm{m}$. Hasil ini mengkonfirmasi penjelasan sebelumnya dimana besaranya ukuran partikel yang digunakan akan memperkecil luas kontak antara koagulan dan partikel koloid.

\section{KESIMPULAN}

Dosis biji kelor terbaik untuk efluen proses aerobik adalah $2.000 \mathrm{ppm}$ dan untuk efluen proses kombinasi anaerobik-aerobik adalah $4.000 \mathrm{ppm}$ dengan penurunan tingkat kekeruhan sebesar $78,28 \%$ dan $58,80 \%$. Secara umum penggunaan dosis koagulan yang berlebihan akan meningkatkan kekeruhan karena kelebihan partikel koagulan akan meningkatkan kadar TSS dalam limbah. Untuk ukuran partikel koagulan, penggunaan koagulan dengan ukuran kecil akan memperluas kontak permukaan koagulan dengan pertikel koloid. Diperolehukuran partikel optimum yaitu $500 \mu \mathrm{m}$ dengan efisiensi penurunan untuk efluen proses aerobik sebesar $94,57 \%$ dan untuk efluen proses kombinasi anaerobik-aerobik sebesar $78,28 \%$.

\section{DAFTAR PUSTAKA}

Freitas, T. K. F. S., Oliveira, V. M., Souza, M. T. F. De, Geraldino, H. C. L., Almeida, V. C., Fávaro, S. L., \& Garcia, J. C. (2015). Optimization of coagulationflocculation process for treatment of industrial textile wastewater using okra ( A . esculentus ) mucilage as natural coagulant. Industrial Crops \& Products, 76, 538-544.

Gurnham, C. F. (1955). Principles of industrial waste treatment. New York: John Wiley and Sons, Inc.

Hendrawati, Nurhasni, \& Syamsumarsih. (2003). Penggunaan Biji Asam Jawa ( Tamarindus Indica L.) dan Biji Kecipir (Psophocarpus tetragonolobus L.) sebagai Koagulan Alami dalam Perbaikan Kualitas Air Tanah. Valensi ISSN : 1978- 8193 UIN Syarif Hidayatullah, 3, 2233.

Hidayat, S. (2009). Protein Biji Kelor Sebagai Bahan Aktif Penjernihan Air. Biospesies, 2(2), 12-17.

Hussain, S., Ghouri, A. S., \& Ahmad, A. (2019). Pine cone extract as natural coagulant for puri fi cation of turbid water. Heliyon, 5, e01420.

Klašnja, M., Antov, M., Škrbic, B., \& Šc, M. (2009). Removal of water turbidity by natural coagulants obtained from chestnut and acorn. Bioresource Technology, 100, 6639-6643.

Kristijarti, A. P., Suharto, I., \& Marienna. (2013). Penentuan Jenis Koagulan dan Dosis Optimum untuk Meningkatkan Efisiensi Sedimentasi dalam Instalasi 
Pengolahan Air Limbah Pabrik Jamu X Disusun Oleh: Prof. Dr . Ign Suharto, APU Marieanna, ST Lembaga Penelitian dan Pengabdian kepada Masyarakat Univers.

Mishra, A., \& Bajpai, M. (2006). The flocculation performance of Tamarindus mucilage in relation to removal of vat and direct dyes. Bioresource Technology, 97, 1055-1059.

Oktariany, A., \& Kartohardjono, S. (2018). Effect of Coagulant Dosage on Tofu Industry Wastewater Treatment in Combination with Ultrafiltration
Process using Polysulfone

Membrane. E3S Web of Conferences, 67, 4004.

Rahmaningsih, Y. D., \& Amanda, N. R. (2019). Penambahan Koagulan Biji Asam Jawa dan Biji Kelor dalam Hasil Pengolahan Anaerobik-Aerobik dan Aerobik Limbah Cair Tahu. Politeknik Negeri Bandung.

Wardani, F. A., \& Agung, T. (2016). Pemanfaatan Biji Asam Jawa (Tamarindus Indica) sebagai Koagulan Alternatif dalam Proses Pengolahan Air Sungai. Jurnal Ilmiah Teknik Lingkungan, 7(2), 85-91. 